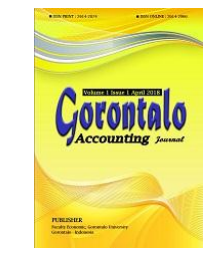

Gorontalo Accounting Journal

https://jurnal.unigo.ac.id/index.php/gaj

Vol 4, No 2, October 2021

P-ISSN: 2614-2074, E-ISSN: 2614-2066

Nationally Accredited Journal, Decree No.36/E/KPT/2019 Sinta 4

\title{
Determinan Terjadinya Fraud di Lingkungan Pemerintahan
}

\author{
Syaipul Rokhim¹, I Made Laut Mertha Jaya ${ }^{2}$ \\ 1,2Universitas Mahakarya Asia, Yogyakarta / Kawasan Kampus STIEBBANK, J1. \\ Magelang No.Km 8, Mlati Glondong, Sendangadi, Kec. Mlati, Kabupaten Sleman, \\ Daerah Istimewa Yogyakarta 55281/Indonesia \\ Emai11,2: syaipulkim29@gmail.com; mad.jaya@yahoo.com
}

Citation: Rokhim, S. \& Jaya, I. M. L. M. (2021). Determinan Terjadinya Fraud di Lingkungan Pemerintahan. Gorontalo Accounting Journal, 4(2), 123-132. DOI: 10.32662/gaj.v4i2.1517

\section{Artikel info}

\section{Artikel history:}

Received: 15-05-2021

Revised:11-08-2021

Accepted: 14-08-2021
Abstract. The 2018 Corruption Perception Index (CPI) data states that Indonesia is in 89th position out of 180 other countries. The purpose of this study is to determine the factors of fraud in the government sector. This study used a sample of 150 employees of government agencies in Indramayu Regency. Data collection by using a questionnaire. The sampling technique uses convenience sampling. Analysis of the data using Structural Equation Modeling (SEM) with smartPLS. The results of the study found that leadership style, effectiveness of internal control, suitability of compensation, organizational ethical culture and law enforcement had no effect on the existence of fraud in the Indramayu Regency Government. Meanwhile, organizational commitment has been shown to have a positive effect on fraud in the Indramayu Regency Government. This study provides a new argument where hard work is needed to eradicate fraud in the government environment. It takes cooperation, commitment, and selfawareness from all elements of society so that fraud can be suppressed.

Abstrak. Data Indeks Persepsi Korupsi (IPK) Tahun 2018 menyebutkan bahwa negara Indonesia berada di posisi ke-89 dari 180 negara lainnya. Tujuan penelitian ini untuk mengetahui faktor-faktor terjadinya fraud di sektor pemerintahan. Penelitian ini menggunakan sampel sebanyak 150 pegawai instansi pemerintahan di Kabupaten Indramayu. Pengumpulan datanya dengan menggunakan kuesioner. Teknik samplingnya menggunakan convenience sampling. Analisis datanya menggunakan Structural Equation Modeling (SEM) dengan smartPLS. Hasil penelitian menemukan bahwa gaya kepemimpinan, keefektifan pengendalian internal, kesesuaian kompensasi, budaya etis organisasi dan penegakan hukum tidak berpengaruh terhadap adanya tindakan fraud di Pemerintahan Kabupaten Indramayu. Sedangkan komitmen organisasi terbukti berpengaruh positif terhadap tindakan fraud di Pemerintahan Kabupaten Indramayu. Penelitian ini memberikan argumen baru dimana perlu kerja keras untuk memberantas kecurangan (fraud) di lingkungan pemerintahan. 
Perlu kerjasama, komitmen, dan kesadaran diri dari semua elemen masyarakat agar fraud dapat ditekan.

Keywords:

Fraud;

Goverment Fraud;

Financial

Accounting

\section{Pendahuluan}

Pemerintahan sebagai pengemban kepercayaan dari masyarakat mempunyai kewajiban untuk melaksanakan tugasnya secara efektif dan efisien. Tujuan tersebut dapat terwujud dengan adanya dukungan dari semua pihak termasuk para pegawainya. Kenyataannya masih ditemukan kasus fraud di lingkungan instansi pemerintahan pusat maupun daerah. Hal ini sangat merugikan negara dan turunnya tingkat kepercayaan masyarakat terhadap pegawai pemerintahan.

Menurut data Indeks Persepsi Korupsi (IPK) Tahun 2018, diperoleh bahwa negara Indonesia berada di posisi ke-89 dengan skor 38 atau naikan sebanyak tujuh tingkat dibandingkan pada tahun 2017 yang berada di posisi ke-96 dengan skor 37 dari 180 negara lainnya. Hasil ini bermakna bahwa negara Indonesia dalam hal banyaknya kasus korupsi masih stagnan. Sedangkan, pada tahun 2019, negara Indonesia berada di posisi ke-85 dengan skor 40, yang artinya penanganan kasus korupsinya sudah "lebih baik" dibandingkan tahun 2017 dan 2018. Nilai IPK ini dihitung secara metodologi oleh Transparansy International dengan skala skor 0-100. Angka 0 menunjukkan "paling korup", sedangkan angka 100 dianggap "paling bersih". Data dari Indonesia Corruption Watch (ICW) pun menyebutkan bahwa penindakan kasus korupsi yang dilakukan selama 1 Januari 2019- 31 Desember 2019 menemukan sebanyak 271 kasus korupsi dengan 580 orang tersangka telah terjadi di pemerintahan pusat maupun daerah. Tingkat kerugian negara mencapai Rp 8,4 triliun. Sedangkan pada tahun 2018 ditemukan sebanyak 454 kasus korupsi dengan 1.087 tersangka dan tingkat kerugian negara mencapai Rp5,6 triliun. Data lainnya dari Komisi Pemberantasan Korupsi juga menyebutkan bahwa sejak lembaga tersebut didirikan hingga per 16 Oktober 2019, jumlah kepala daerah tersangka kasus korupsi di Indonesia terdata sebanyak 120 kepala daerah. Daerah Jawa Barat: 19 orang kepala daerah tersangka, Jawa Timur:14 orang kepala daerah, Sumatra Utara:12 orang kepala daerah, dan Jawa Tengah:10 orang kepala daerah.

Dari berbagai teori, banyak faktor penyebab terjadinya fraud, diantaranya GONE Theory oleh Bologna (1993) dalam (Imam Ardiansyah et al., 2011). Teori ini menjelaskan tentang penyebab fraud, terdiri dari empat faktor yang mendorong seseorang berperilaku menyimpang (fraud), yaitu Greed, Opportunity, Needs, dan Explosure. Fraud Triangle Theory yang dikembangkan oleh Cressey (1953) dalam (Tuasikal, 2017). Teori ini mengatakan bahwa fraud terjadi oleh tiga faktor, yaitu Pressure, Opportunity, dan Rationalization. Pressure terjadi disebabkan adanya tekanan yang dilakukan oleh pihak internal atau eksternal dari seseorang yang melakukan fraud. Indikator tekanan pada penelitian ini diukur melalui gaya kepemimpinan dan kesesuaian kompensasi, sebab gaya kepemimpinan dapat menjadi pengaruh terjadinya fraud di lingkungan pemerintahan. Menurut Flippo (1997) dalam Faisal (2013) gaya kepemimpinan dapat didefinisikan sebagai pola tingkah laku yang dirancang untuk mengintegrasikan tujuan organisasi dengan tujuan individu untuk mencapai suatu tujuan tertentu. Ketidakpuasan karena kompensasi yang tidak memadai atau pekerjaan yang menjemukan juga dapat mendukung insiden-insiden pencurian oleh para pegawai (Zulkarnain, 2013). 
Pernyataan ini mengasumsikan bahwa pegawai yang mengalami ketidakpuasan dengan gajinya akan cenderung mencari penghasillan lain seperti dengan melakukan fraud.

Elemen opportunity merupakan elemen yang paling memungkinkan untuk diminimalisir melalui penerapan proses, prosedur, kontrol dan upaya dan upaya deteksi dini. Semakin baik pengendalian internal birokrasi pemerintahan, maka semakin rendah kecurangan akuntansi pemerintah. Pelaku fraud selalu berusaha untuk melegitimasi perbuatannya dengan berupaya untuk mencari-cari alasan pembenarannya (rationalization). Hal ini dilakukan untuk menenangkan perasaan yang bersangkutan, sehingga jika dilakukan tidak menimbulkan ketakutan dalam dirinya. Menurut (Fitri \& Nadirsyah, 2020)rasionalisasi ini diproksikan dengan adanya kesenjangan integritas manajemen dan hubungan yang tidak baik antara manajer dan auditor. Diargumentasikan pula oleh (Jaya, 2020), bahwa dalam suatu lingkungan yang lebih etis, pegawai akan cenderung mengikuti peraturan perusahaan dan peraturan-peraturan tersebut akan menjadi perilaku secara moral dan bisa diterima. Sehingga, dapat diasumsikan bahwa lingkungan etis organisasi yang buruk dapat mempengaruhi pegawai dalam melakukan tindakan kecurangan. Jadi, semakin baik lingkungan etis organisasi dalam suatu pemerintahan, maka akan semakin rendah tingkat terjadinya fraud di sektor pemerintahan.

(Pristiyanti, 2012) juga mengatakan lingkungan yang etis dari suatu organisasi meliputi aspek dari gaya top manajemen dalam mencapai sasaran organisasitoris, nilai-nilai mereka dan gaya manajemen atau kepemimpinannya, diargumentasikan bahwa di suatu lingkungan yang lebih etis, pegawai akan cenderung untuk mengikuti peraturan perusahaan dan peraturan-peraturan tersebut akan menjadi perilaku secara moral dan bisa diterima sehingga dapat dikatakan bahwa dalam lingkungan yang etis dibentuk oleh gaya kepemimpinan yang baik, akan berpengaruh terhadap kecenderungan kecurangan yang dilakukan pegawai.Sistem pengendalian internal bagi sebuah organisasi sangatlah penting, yaitu untuk memberikan perlindungan bagi entitas terhadap kelemahan manusia serta untuk mengurangi kemungkinan kesalahan dan tindakan yang tidak sesuai dengan peraturan. Semakin tinggi (efektif) kepatuhan pegawai terhadap sistem pengendalian intern yang diterapkan suatu instansi maka akan semakin rendah tingkat fraud di sektor pemerintahan yang dapat terjadi.

Komitmen organisasi secara umum mengacu pada sikap-sikap dan perasaan karyawan dihubungkan dengan nilai-nilai dan cara perusahaan itu melakukan berbagai hal (Najahningrum, 2013; Pramudita, 2013; Wijayanti \& Hanafi, 2018). Dalam hal ini termasuk juga dalam melakukan tindakan fraud atau kecurangan. Apabila pegawai di suatu organisasi mempunyai komitmen organisasi yang tinggi terhadap organisasinya hal ini dapat menurunkan tingkat terjadinya fraud di sektor pemerintahan. Di dalam penelitian yang dilakukan oleh (Rakhmat, 2013; Riduwan, 2010) menunjukkan bahwa di suatu lingkungan yang lebih etis, seorang karyawan akan lebih cenderung melakukan atau menjalankan peraturanperaturan perusahaan, dan menghindari perbuatan kecurangan di dalam instansi, lingkungan etis ini dapat dinilai dengan adanya budaya etis organisasi dan komitmen organisasi, begitu pun (Pramudita, 2013) yang menyatakan bahwa suatu perilaku tidak etis di dalam organisasi itu timbul karena adanya lingkungan etis yang buruk. Kecurangan merupakan suatu tindakan manyimpangan dari hukum yang berlaku. Kecurangan dapat disebabkan oleh adanya ketidaksadaran akan pentingnya menaati hukum/peraturan maupun kurangnya ketegasan dalam penegakan hukum/peraturan. Kebanyakan masyarakat mengerti tentang hukum, tetapi tidak mematuhinya. 
Beberapa penelitian yang berkaitan dengan kecurangan (fraud) dan variabelvariabel yang berkaitan dalam penelitian ini diantaranya (Faisal, 2013; Imam Ardiansyah et al., 2011; Jaunanda, Giovani, Anton, \& Susanto, 2020; Mertha Jaya \& Ambarwati, 2019; Najahningrum, 2013; Pristiyanti, 2012; Septriyani \& Handayani, 2018; Wiguna \& Eka Hariyani, 2018). Relevansi penelitian ini dengan penelitian sebelumnya adalah sama-sama menguji faktor-faktor yang mempengaruhi kecenderungan kecurangan akuntansi (fraud) dengan menggunakan obyek penelitian lain, yaitu di lingkungan pemerintahan Kabupaten Indramayu.

Teori yang digunakan penelitian ini guna mempelajari proses bagaimana seseorang menginterpretasikan sesuatu peristiwa, alasan, atau sebab perilakunya (Jaya, 2020; Soegiono, 2012; Svabova, Kramarova, Chutka, \& Strakova, 2020), yaitu teori atribusi. Teori ini menyarankan bahwa jika seseorang mengamati seseorang individu, orang tersebut akan berusaha menentukan apakah perilaku itu disebabkan oleh faktor internal atau eksternal. Relevansi penggunaan grand teori tersebut juga dapat menjelaskan faktor-faktor yang dapat mempengaruhi terjadinya fraud di Pemerintahan Kabupaten Indramayu yang digunakan pada penelitian ini.

Di suatu lingkungan yang lebih etis, pegawai akan cenderung untuk mengikuti peraturan perusahaan dan peraturan-peraturan tersebut akan menjadi perilaku secara moral dan bisa diterima, sehingga dapat dikatakan bahwa dalam lingkungan yang etis dibentuk oleh gaya kepemimpinan yang baik, akan berpengaruh terhadap kecenderungan kecurangan yang dilakukan pegawai (Septriyani \& Handayani, 2018). Penelitian (Septriyani \& Handayani, 2018) berpendapat bahwa lingkungan yang lebih etis dapat dinilai dengan adanya budaya etis organisasi dan komitmen organisasi. perilaku yang tidak etis di dalam organisasi dapat timbul karena adanya lingkungan etis yang buruk (Pramudita , 2013). Kondisi ini mengharuskan sistem pengendalian internal organisasi untuk dapat memberikan perlindungan bagi entitas terhadap kelemahan manusia serta untuk mengurangi kemungkinan kesalahan dan tindakan yang tidak sesuai dengan peraturan (Imam Ardiansyah et al., 2011; Maulana Saud, Taufiqul Hakim, \& Lulu Dyar, 2020; Wijayanti \& Hanafi, 2018). Sedangkan, komitmen organisasi lebih menekankan pada proses pegawai ketika mengidentifikasi dirinya dengan nilai-nilai, aturan-aturan, dan tujuan organisasi (Mertha Jaya \& Ambarwati, 2019).

Suatu kompensasi yang tidak adil atau tidak memadai serta pekerjaan yang menjemukan, juga dapat mendukung insiden-insiden pencurian oleh para pekerja, dalam hal ini adalah pencurian aset perusahaan atau organisasi tersebut (Zulkarnain, 2013). Pemberian kompensasi yang sesuai dengan pekerjaan yang dilakukan oleh pegawai dapat membuat pegawai merasa tercukupi, sehingga akan meningkatkan kinerja pegawai dan mengurangi tindakan kecurangan (fraud). Penegakan hukum juga dikategorika sebagai suatu tindakan nyata oleh subjek hukum terhadap hukum yang berlaku di suatu Negara (Tuasikal, 2017). Berdasarkan uraian yang telah disajikan tersebut, maka dirumuskan beberapa hipotesis sebagai berikut.

$\mathbf{H}_{\mathbf{1}}$ : Gaya kepemimpinan mempengaruhi Fraud secara negatif di sektor pemerintahan.

$\mathbf{H}_{2}$ : Keefektifan sistem pengendalian internal mempengaruhi Fraud secara negatif di sektor pemerintahan.

$\mathbf{H}_{3}$ :Komitmen Organisasi mempengaruhi Fraud secara negatif di sektor pemerintahan.

$\mathbf{H}_{\mathbf{4}}$ : Kesesuaian Kompensasi mempengaruhi Fraud secara negatif di sektor pemerintahan. 
$\mathbf{H}_{5}$ : Budaya etis organisasi mempengaruhi Fraud secara negatif di sektor pemerintahan.

$\mathbf{H}_{6}$ : Persepsi penegakan hukum mempengaruhi Fraud secara negatif di sektor pemerintahan.

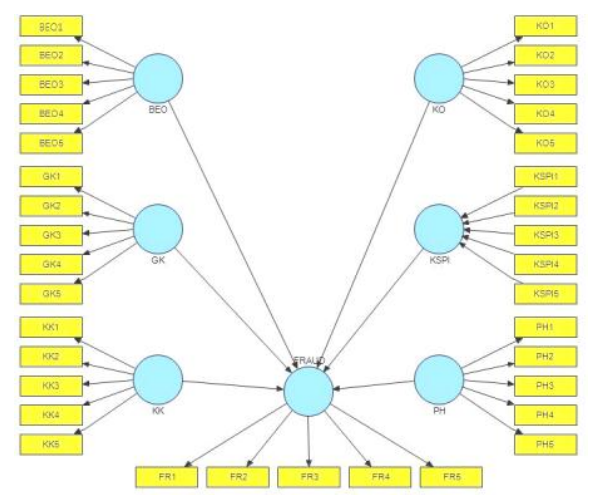

Gambar 1. Kerangka Model Penelitian

\section{Metode Penelitian}

Penelitian kuantitatif ini melakukan uji dengan data primer. Data primer diperoleh melalui survei menggunakan kuesioner yang diberikan kepada pegawai Pemerintahan Kabupaten Indramayu, Jawa Barat. Kuesioner yang disusun berisi tentang persepsi pegawai mengenai faktor-faktor yang mempengaruhi kecurangan (fraud)(Jaya, 2020)

Populasi penelitian terdiri dari seluruh pegawai negeri sipil di Pemerintahan Dinas Kabupaten Indramayu, Jawa Barat. Peneliti juga melakukan sampling atau meneliti beberapa populasi yang mewakili (Jaya, 2020). Teknik convenience sampling dipilih dalam mengumpulkan informasi melalui anggota populasi yang bersedia memberikan respon terhadap kuesioner yang diberikan (Sugiyono, 2011). Hal ini juga dikarenakan sulitnya menemui pegawai instansi yang rela untuk dijadikan responden disebabkan kesibukannya. Kondisi ini membuat peneliti melakukan pemetaan responden dari 10 kantor dinas yang ada di Kabupaten Indramayu, peneliti mengambil sampel 15 PNS untuk masing-masing dinas. Total sampelnya diperoleh sebanyak 150 PNS. Kuesioner yang akan ditabulasi datanya adalah kuisioner yang kembali dalam keadaan diisi lengkap. Berikut ini daftar instansi pemerintah yang ada di Kabupaten Indramayu, yaitu Dinas Tenaga Kerja, Dinas Perikanan dan Kelautan, Dinas Pertanian, Dinas Kependudukan dan Pencatatan Sipil, Dinas Komunikasi dan Informatika, Dinas Perumahan, Kawasan Permukiman dan Pertahanan, Dinas Ketahanan Pangan, Dinas PUPR/Bina Marga, Dinas Sosial, dan Dinas Peternakan dan Kesehatan Hewan.

Tabel 1. Indikator Variabel dan Pengukurannya

\begin{tabular}{lll}
\hline \multicolumn{1}{c}{ Variabel } & Pengukuran & \multicolumn{1}{c}{ Indikator pertanyaan } \\
\hline Kepemimpinan & Skala Likert & $\begin{array}{l}\text { Relasi pemimpin dengan anggota, Struktur tugas, } \\
\text { Posisi kekuatan, Delegasi tugas, Etika pemimpin } \\
\text { (Desai, Roberts, \& Srivastava, 2010). }\end{array}$ \\
\hline Keefektifan & Skala Likert & $\begin{array}{l}\text { Gembira memilih bekerja pada } \\
\text { organisasi,Penaksiran resiko, Aktifitas } \\
\text { pengendalian, Informasi dan komunikasi, } \\
\text { Pemantauan (Mertha Jaya \& Ambarwati, 2019). }\end{array}$ \\
\hline
\end{tabular}




\begin{tabular}{lll}
\hline \multicolumn{1}{c}{ Variabel } & Pengukuran & \multicolumn{1}{c}{ Indikator pertanyaan } \\
\hline $\begin{array}{l}\text { Kesesuaian } \\
\text { Kompensasi }\end{array}$ & Skala Likert & $\begin{array}{l}\text { Kompensasi keuangan, pengakuan dari } \\
\text { perusahaan, Ketidakadilan dengan pembagian } \\
\text { kompensasi, promosi, dan penyelesaian tugas, } \\
\text { (Mertha Jaya \& Poerwono, 2019). }\end{array}$ \\
\hline $\begin{array}{l}\text { Budaya etis } \\
\text { organisasi }\end{array}$ & Skala Likert & $\begin{array}{l}\text { Model peran yang visibel, Komunikasi harapan- } \\
\text { harapan etis, Pelatihan etis, Hukuman bagi } \\
\text { tindakan tidak etis, Mekanisme perlindungan etika } \\
\text { (Desai et al., 2010). }\end{array}$ \\
\hline $\begin{array}{l}\text { Komitmen } \\
\text { organisasi }\end{array}$ & Skala Likert & $\begin{array}{l}\text { Bekerja melalui target, Membanggakan organisasi } \\
\text { kepada orang lain, Menerima semua tugas } \\
\text { Kesamaan nilai, Bangga menjadi bagian organisasi } \\
\text { (Mertha Jaya \& Ambarwati, 2019). }\end{array}$ \\
\hline $\begin{array}{l}\text { Penegakan } \\
\text { hukum }\end{array}$ & Skala Likert & $\begin{array}{l}\text { Daya tanggap pejabat penerima lamban, Proses } \\
\text { penegakan hukum pidana selesai, Putusan } \\
\text { pengadilan sesuai dengan fakta-fakta hukum, } \\
\text { Aturan hukum dalam instansi Ketaatan terhadap } \\
\text { hukum (Tuasikal, 2017). }\end{array}$ \\
\hline $\begin{array}{l}\text { Fraud di } \\
\text { sektor }\end{array}$ & Skala Likert & $\begin{array}{l}\text { Kecurangan laporan keuangan, Penyalahgunaan } \\
\text { Pemerintahan } \\
\text { Jaya \& Ambaruati, Ketiadaan bukti transaksi (Mertha }\end{array}$ \\
\hline
\end{tabular}

Penelitian ini menggunakan teknik analisis SEM (Structural Equation Modeling). Dikarenakan uji SEM lebih memungkinkan dilakukannya analisis di antara beberapa variabel dependen dan independen secara langsung juga (Sugiyono, 2011). Model persamaan penelitiannya sebagai berikut.

$$
\mathbf{Y}=\mathbf{a}+\beta_{1} \mathbf{X}_{1}+\beta_{2} \mathbf{X}_{2}+\beta_{3} \mathbf{X}_{3}+\beta_{4} \mathbf{X}_{4}+\varepsilon
$$

Keterangan:

$\mathrm{Y}=$ Variabel dependen (Fraud)

$\mathrm{a}=$ Konstanta

$\mathrm{X}_{1}=$ Variabel Gaya Kepempinan

$\mathrm{X}_{2}=$ Variabel Keefektifan SPI

$\mathrm{X}_{3}=$ Variabel Kesesuaian Kompensasi

$\mathrm{X}_{4}=$ Variabel Budaya Etis Organisasi

$\mathrm{X}_{5}=$ Variabel Komitmen Organisasi

$\mathrm{X}_{6}=$ Variabel Penegakan hukum

$\varepsilon=$ error

\section{Hasil Dan Pembahasan} berikut :

Hasil Uji antar variabel independen dengan dependen ditampilkan sebagai 


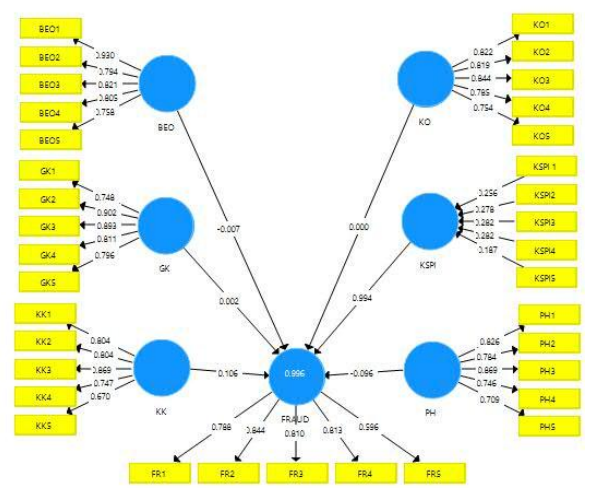

Gambar 2. Hasil uji SEM

Menurut hasil uji pada Gambar 1 ditemukan bahwa tidak terdapat nilai loading factor di bawah 0.50 .

Tabel 2. Uji Hipotesis Berdasarkan Path Coefficient

\begin{tabular}{lcccc}
\hline & $\begin{array}{c}\text { Original Sample } \\
(\mathbf{O})\end{array}$ & $\begin{array}{c}\text { Sample } \\
\text { Mean (M) }\end{array}$ & $\begin{array}{c}\text { Standard Error } \\
\text { (STERR) }\end{array}$ & $\begin{array}{c}\text { T Statistics } \\
(\mid \mathbf{O} / \text { STERR|) }\end{array}$ \\
\hline BEO $\rightarrow$ FRAUD & -0.00699 & -0.00474 & 0.00701 & 0.99685 \\
\hline GK $\rightarrow$ FRAUD & 0.00246 & -0.00202 & 0.00614 & 0.39999 \\
\hline KK $\rightarrow$ FRAUD & 0.10601 & -0.06858 & 0.09476 & 1.11872 \\
\hline KO $\rightarrow$ FRAUD & 0.00018 & -0.00074 & 0.00672 & 0.0274 \\
\hline KSPI $\rightarrow$ FRAUD & 0.99398 & -0.995 & 0.00347 & 286.4563 \\
\hline PH $\rightarrow$ FRAUD & -0.09645 & -0.05972 & 0.09545 & 1.01042 \\
\hline
\end{tabular}

Sumber: Output PLS, 2020.

Berdasarkan hasil perhitungan tabel 2 diketahui bahwa gaya kepemimpinan tidak berpengaruh terhadap Fraud di sektor pemerintahan. Hal itu dikarenakan nilai $t$-statistic sebesar 0,39999 ( $\mathrm{p}>0.05)$. Dengan demikian $\mathbf{H}_{\mathbf{1}}$ tidak diterima. Temuan ini menjelaskan bahwa selama ini komunikasi yang terjadi antara bawahan dengan atasan di kantor pemerintahan Kabupaten Indramayu belum terjalin dengan sangat baik. Kondisi ini mengakibatkan adanya dugaan munculnya perilaku fraud di lingkungan pemerintahan. Hasil temuan ini mendukung penelitian (Faisal, 2013; Zulkarnain, 2013)dimana ketika tidak terjadi komunikasi yang baik, maka asimetri informasi mengakibatkan munculnya perilaku fraud di lapisan kantor pemerintahan.

Keefektifan sistem pengendalian internal tidak mempengaruhi Fraud di sektor pemerintahan. Nilai $\mathrm{p}>0.05$ atau nilai $t$-statistic sebesar 286,4563 menyimpulkan jika $\mathbf{H}_{2}$ tidak diterima. Pemerintahan Kabupaten Indramayu perlu untuk melakukan efektifitas terhadap sistem pengendalian internalnya agar dapat mengurangi perilaku fraud di lingkungannya. Temuan ini mendukung penelitian (Maulana Saud et al., 2020) bahwa semakin efektif sistem pengendalian internal organisasi, maka semakin sulit ruang seseorang untuk melakukan kecurangan di aktivitasnya dan sebaliknya ketika seseorang dapat melakukan kecurangan, maka diduga sistem pengendalian internalnya belum efektif dalam memantau segala aktivitas operasi organisasi tersebut.

Hasil uji juga menunjukkan bahwa komitmen organisasi mempengaruhi terhadap Fraud di sektor pemerintahan secara positif. Simpulan ini dibuktikan dengan nilai $t$-statistic sebesar 0,0274 tidak signifikan pada $(\mathrm{p}<0.05)$. Dengan demikian $\mathbf{H}_{\mathbf{3}}$ tidak diterima. Temuan ini mendukung penelitian (Wardhani, 2015) 
yang menunjukkan bahwa atasan atau pimpinan di sebuah organisasi pemerintahan belum sepenuhnya memberikan arahan dan percontohan yang baik kepada para pegawainya untuk lebih berkomitmen di dalam menjalankan tugasnya, sehingga fraud masih dapat terjadi. Meskipun tidak semua pimpinan memberikan contoh buruk, namun data survey yang kami peroleh memberikan hasil yang sesuai dengan fakta saat ini.

Berdasarkan tabel 2 diketahui bahwa kesesuaian kompensasi tidak mempengaruhi Fraud di sektor pemerintahan. Temuan ini dibuktikan dengan nilai $t$-statistic sebesar 1,11872 tidak signifikan pada ( $\mathrm{p}>0.05)$. Hasil ini menyimpulkan bahwa $\mathbf{H}_{\mathbf{4}}$ tidak diterima. Berdasarkan kegiatan survey yang telah dilakukan menunjukkan bahwa pengakuan organisasi terhadap keberhasilan pegawainya dalam melaksanakan pekerjaan belum sepenuhnya diakui oleh instansi. Hasil penelitian ini mendukung penelitian (Mertha Jaya \& Ambarwati, 2019)yang menyatakan bahwa kondisi dimana pegawai merasa jika bekerja dengan beban sama atau pun tidak mereka tetapa memperoleh hasil yang sama. Hal ini tentu perlu dilakukan evaluasi agar kompensasi yang diterima setiap pegawai sesuai dengan kinerjanya, sehingga menciptakan iklim organisasi yang fairness.

Budaya etis organisasi juga tidak mempengaruhi Fraud di sektor pemerintahan, dikarenakan nilai $t$-statistic sebesar 0.99685 ( $\mathrm{p}>0.05)$. Dengan demikian $\mathbf{H}_{\mathbf{5}}$ tidak diterima. Hasil ini mendukung penelitian (Wijayanti \& Hanafi, 2018) yang menunjukkan bahwa budaya organisasi yang selama ini dibentuk dan dirancang serta didokumentasikan di setiap organisasi pemerintahan hanya dianggap sebagai nilai tambah, tanpa adanya kedisiplinan untuk mematuhi dan menjalankannya dengan sungguh-sungguh, sehingga perilaku fraud masih dapat terjadi saat ini.

Penegakan hukum juga tidak mempengaruhi Fraud di sektor pemerintahan, dikarenakan nilai $t$-statistic sebesar $1,01042(\mathrm{p}>0.05)$. Dengan demikian $\mathbf{H}_{\mathbf{6}}$ tidak diterima, hasil ini menunjukkan bahwa penegakan hukum pegawai instansi di pemerintahan saat ini masih belum tajam, sehingga belum dapat menekan tingkat terjadinya fraud di sektor pemerintahan. Sepertinya hasil uji ini sesuai dengan kondisi saat ini dimana penegakan hukum di Indonesia bagi pelaku kecurangan (fraud) atau pun koruptor masih terlalu ringan, sehingga sampai saat ini pun siapa pun tidak ada yang merasa takut untuk berbuat curang. Seharusnya kita semuanya mulai bersikap untuk saling berkomitmen dan menegakkan hukum secara penuh dan tidak memihak agar perilaku kecurangan (fraud) dapat ditekan seperti yang dinyatakan oleh (Nugroho \& Elviandri, 2018).

\section{Kesimpulan Dan Saran}

Tahapan uji analisis data, pemaparan teori serta beberapa referensi penelitian terdahulu yang telah disajikan, menyimpulkan bahwa gaya kepemimpinan, komitmen organisasi, kesesuaian kompensasi, budaya etis organisasi, dan penegakan hukum organisasi tidak mempengaruhi fraud di sektor pemerintahan Kabupaten Indramayu.

Saran bagi pemerintah Kabupaten Indramayu, Jawa Barat, yaitu agar lebih memperhatikan pemberian penghargaan bagi para pegawai sesuai dengan kinerjanya, sehingga pegawai lebih merasa puas dengan prestasi kerjanya. Dapat melakukan pemeriksa fisik atas asset instansi lebih optimal agar dapat terpantau dengan baik keberadaannya. Para pegawai instansi pemerintahan Kabupaten Indramayu untuk meningkatkan rasa bangga pegawai instansi pemerintah terhadap organisasinya dengan cara lebih mencintai pekerjaan mereka.Instansi pemerintahan Kabupaten Indramayu perlu mengadakan seminar dan pelatihan etis tentang standar organisasi bagi para pegawai di instansi. 
Keterbatasan penelitian ini yaitu sulitnya data yang diperoleh karena sebagian besar pegawai pemerintahan Kabupaten Indramayu banyak yang sibuk dengan pekerjaan lainnya, sehingga hanya beberapa saja yang bersedia mengisinya. Penelitian selanjutnya sebaiknya menggunakan data responden yang mudah ditemui agar mempercepat proses penelitian dan pengujian datanya.

\section{Pengakuan}

Penulis memberikan penghargaan dan pengakuan terhadap pihak-pihak yang membantu selesainya penelitian ini, terutama beberapa responden, yaitu Bapak/Ibu Pegawai Negeri Sipil di Pemerintahan Kabupaten Indramayu, Jawa Barat yang terdiri dari Dinas Tenaga Kerja, Dinas Perikanan dan Kelautan, Dinas Pertanian, Dinas Kependudukan dan Pencatatan Sipil, Dinas Komunikasi dan Informatika, Dinas Perumahan, Kawasan Permukiman dan Pertahanan, Dinas Ketahanan Pangan, Dinas PUPR/Bina Marga, Dinas Sosial, dan Dinas Peternakan dan Kesehatan Hewan.

\section{Daftar Pustaka}

Desai, V., Roberts, R. W., \& Srivastava, R. (2010). An analytical model for external auditor evaluation of the internal audit function using belief functions. Contemporary Accounting Research, 27(2), 537-575. https://doi.org/10.1111/j.1911-3846.2010.01016.x

Faisal, M. (2013). Analisis Fraud Di Sektor Pemerintahan Kabupaten Kudus. Accounting Analysis Journal, 2(1). https://doi.org/10.15294/aaj.v2i1.1181

Fitri, F., \& Nadirsyah, N. (2020). Pengaruh Tekanan (Pressure), Kesempatan (Opportunity), Rasionalisasi (Rationalization), Dan Kapabilitas (Capability) Terhadap Kecurangan Pengadaan Barang/Jasa Di Pemerintahan Aceh Dengan Pemoderasi Budaya Etis Organisasi. Jurnal Ilmiah Mahasiswa Ekonomi Akuntansi, 5(1), 69-84. https://doi.org/10.24815/jimeka.v5i1.15437

Imam Ardiansyah, Herawati, H., Ekawati, D., Hermansyah, W., Mangoting, Y., Sukoharsono, E. G., Pamungkas, I. D. (2011). Business culture and tax evasion: Why corruption and the unofficial economy can persist. International Journal of Financial Research, 4(2), 811-822. https://doi.org/10.5430/ijfr.v11n4p316

Jaunanda, M., Giovani, N., Anton, R., \& Susanto, T. R. (2020). Analisis Sistem Pengendalian Internal Siklus Persediaan Pada PT . Surya Toto Indonesia Tbk ( Subsektor Fitting ). Jurnal Akuntansi Keuangan Dan Bisnis, 13(2), 40-49.

Jaya, I. M. L. M. (2020). Metode Penelitian Kuantitatif Dan Kualitatif: Teori, Penerapan, dan Riset Nyata. Yogyakarta, Indonesia: Anak Hebat Indonesia.

Jaya, I. M. L. M. \& I. M. N. (2020). The Beauty and the Beast of Earning Management in Indonesia. Opcion, 36(91), 1097-1140. Retrieved from https:// produccioncientificaluz.org/index.php/opcion/article/view/32496

Maulana Saud, I., Taufiqul Hakim, A., \& Lulu Dyar, dan. (2020). Analisis Determinan Fraud Prevention (Studi Empiris Pada Badan Usaha Milik Daerah di D.I Yogyakarta dan Jawa Tengah). Jurnal Akuntansi Keuangan Dan Bisnis, 13(2), 1-10. Retrieved https://jurnal.pcr.ac.id/index.php/jakb/article/view/3604

Mertha Jaya, I. M. L., \& Ambarwati, A. A. (2019). Pengujian Teori Fraud Pentagon Terhadap Kecurangan Laporan Keuangan Pada Perusahaan Pertambangan di Indonesia. Akuntabilitas: Jurnal Ilmu Akuntansi, 12(September), 157-168. https://doi.org/10.15408/akt.v12i2.12587

Mertha Jaya, I. M. L., \& Poerwono, A. A. A. (2019). Pengujian Teori Fraudpentagon Terhadap Kecurangan Laporan Keuangan Pada Perusahaan pertambangan di 
Indonesia.

Akuntabilitas, https://doi.org/10.15408/akt.v12i2.12587

12(2),

$157-168$.

Najahningrum, A. F. (2013). Faktor-faktor yang mempengaruhi fraud: persepsi pegawai. Accounitng Analysis Journal, 2(3), 259-267. Retrieved from http://journal.unnes.ac.id/sju/index.php/aaj\%OAFAKTOR-FAKTOR

Nugroho, S. S., \& Elviandri. (2018). Memayu Hayuning Bawana: Melacak Spiritualitas Transendensi Hukum Pengelolaan Sumber Daya Alam Berbasis Kearifan Masyarakat Jawa. Pengembangan Dan Penegakan Hukum Di Indonesia, (1), 346-355.

Pramudita, A. (2013). Analisis Fraud Di Sektor Pemerintahan Kota Salatiga. Accounting Analysis Journal, 2(1). https://doi.org/10.15294/aaj.v2i1.1156

Pristiyanti, I. ruly. (2012). Persepsi Pegawai Instansi Pemerintah Mengenai FaktorFaktor Yang Mempengaruhi Fraud Di Sektor Pemerintahan. Accounting Analysis Journal, 1(1). https://doi.org/10.15294/aaj.v1i1.707

Rakhmat, M. (2013). Etika Dasar Setiap Profesi Kehidupan dalam Perspektif Hukum Positif, 1-95.

Riduwan, A. (2010). Etika Dan Perilaku Koruptif Dalam Praktik Manajemen Laba: Studi Hermeneutika, 1(1), 1-21.

Septriyani, Y., \& Handayani, D. (2018). Mendeteksi Kecurangan Laporan Keuangan dengan Analisis Fraud Pentagon. Jurnal Akuntansi, Keuangan Dan Bisnis, 11(1), 11-23. Retrieved from http://jurnal.pcr.ac.id

Soegiono, T. (2012). Filsafat Pendidikan Teori dan Praktik. Bandung: PT. Remaja Rosdakarya.

Sugiyono. (2011). Metode Penelitian Kuantitatif, Kualitatif dan R\&N. Bandung: Alfabeta.

Svabova, L., Kramarova, K., Chutka, J., \& Strakova, L. (2020). Detecting earnings manipulation and fraudulent financial reporting in Slovakia. Oeconomia Copernicana, 11(3), 485-508. https://doi.org/10.24136/OC.2020.020

Tuasikal, H. (2017). Akutansi Forensik Dalam Upaya Pemberantasan Tindak Pidana Korupsi. Al Daulah: Jurnal Hukum Pidana Dan Ketatanegaraan, 6(2), 199-205. https://doi.org/10.24252/ad.v6i2.4876

Wardhani, R. martini;Kartika rachmasari; R. susi. (2015). Analisis Penerapan Good University Governance Melalui Efektivitas Pengendalian Intern Dan Komitmen Organisasional. Angewandte Chemie International Edition, 6(11), 951-952.

Wiguna, M., \& Eka Hariyani, dan. (2018). Effect of Tax Rate, Taxation Technology and Information, Possibility of Fraud Detection, and Tax Fairnesson Taxpayer Perception of Tax Fraud Ethics (Empirical Study on KPP Pekanbaru, Dumai, Rokan Hilir), 11(1), 24-30. Retrieved from http://jurnal.pcr.ac.id

Wijayanti, P., \& Hanafi, R. (2018). Pencegahan Fraud pada Pemerintahan Desa. Jurnal Akuntansi Multiparadigma, 9(2), 331-345.

Zulkarnain, R. M. (2013). Analisis Faktor Yang Mempengaruhi Terjadinya Fraud Pada Dinas Kota Surakarta. Accounting Analysis Journal, 2(2). https://doi.org/10.15294/aaj.v2i2.2852 